\title{
セルラーゼ処理による部分カルボキシメチル化綿のモルホロジー観察
}

\author{
東海染工株式会社テクノセンター 山田 稔 \\ 信州大学工学部物質工学科年野良彦・野崎功一・神田鷹久
}

\section{Morphological Observation of Partially Carboxymethylated Cotton Treated by Cellulase}

\author{
Minoru Yamada $^{* 1, * 2}$, Yoshihiko Amano $^{* 2}$, Kouichi Nozaki $^{* 2}$, and Takahisa Kanda ${ }^{* 2}$ \\ ${ }^{* 1}$ Techno Center, Tokai Senko K.K., 1-2 Neshinden, Nishibiwajima-cho, \\ Nishikasugai-gun, Aichi 452-0068, Japan \\ ${ }^{* 2}$ Department of Chemistry and Material Engineering, Faculty of Engineering, \\ Shinshu University, 4-17-1 Wakasato, Nagano 380-8553, Japan
}

\begin{abstract}
In our previous paper, cotton fabrics which had been modified by carboxymethylation so as to have the degree of substitution of $0.02 \sim 0.16$ were treated with a commercial cellulase preparation. The modification by carboxymethylation for cotton fabrics apparently inhibited weight loss activity and saccharification activity of cellulase. In this study, by scanning electron microscopy, we observed morphological changes of fiber surface of modified cotton fabrics treated with a commercial cellulase preparation. For unmodified cotton fabrics, deep bias cracks were produced and clear fibrillar layers appeared on the fiber surface by synergistic reaction of cellulase components. On the other hand, for cotton fabrics modified by carboxymethylation, we observed inhibition of catalytic reaction of some cellulase components, as a result of no deep cracks and no appearance of fibril layers on fibers. In addition, we confirmed, by measurements of FT-IR spectra and K/S values of fabrics dyed with a basic dye, that carboxymethyl groups in modified cotton fabrics remained even after treatment with cellulase. From these results, it is suggested that the change in the activity of each cellulase component on modified cotton can affect the synergistic action of cellulases, and consequently the morphology of fiber surface of modified cotton changes compared with unmodified cotton.
\end{abstract}

(Received 9 July, 2004; Accepted 7 October, 2004)

\section{1. 緒 言}

繊維工業において近年セルラーゼの利用が定着してい るが 1 - 3]，実際の工業的生産においては繊維に結合した 染料や染色助剂がセルラーゼの作用を阻害し[ 4 8]，光の 反応機構をより複雑にしている.一方 , カルボキシメチル セルロース (以下， CMC という) は一般に水溶性の高分子 であり，セルラーゼの酵素活性の測定にも利用され，CMC に対するセルラーゼの作用機構は多く報告されている [ 9-12] . 前報[ 13]では, セルラーゼの作用がよく研究され ているCMCの知見を基に 綿䋐維の一部に染料よりも分子 がコンパクトなカルボキシメチル基を導入した .すなわち， 綿を高結晶性で不溶性のまま，一部の水酸基をカルボキシ メチル化（以下，CM化という）した繊維布帛を作成し， 产の改質の度合いによりセルラーゼがどのように作用す るかを報告した . 光の際, イオン性を考慮し,ナトリウム (Na) 塩型の CMG Na 布と酸型の CMG H 布についてセルラ 一ゼの作用を比較した . 即ち, セルラーゼの作用を布帛の
重量変化(減量率)と酵素処理液中に生成する還元糖量(グ ルコース換算) の観点から報告した . 兴の結果 , 改質によ りセルラーゼの作用が阻害されることを確認した . また， 改質セルロースに対するセルラーゼ各成分の作用は， $D S$ (置換度) $=0.10$ までは不溶性基質として挙動している ことが示唆された .さらに, DS=0.16においては, 繊維の 膨潤が大きくなり，特に CMC Na 布においてはエンド型成 分の作用により減量率が急激に増大した.更に,脱離した 微細なポリマーや水溶性のオリゴマーに対するエキソ型 成分の作用により，還元糖量も増加した。

そこで，本論文では CM化綿布のうち顕著に性質を異に する $\mathrm{DS}=0.10$ (不溶性基質として作用) と $\mathrm{DS}=0.16$ (膨 潤により一部水溶性基質として作用)の CM化布について， 走査型電子顕微鏡 (SEM) を用いてモルホロジー観察を行 い,改質綿布に対するセルラーゼ各成分の役割について報 告する.また，フーリ工変換赤外分光法 (FT-IR) による 赤外吸収スペクトルと塩基性染料による染着性から繊維 表面の改質程度の変化を考察する。 


\section{2. 実 験}

\section{1 試料および酵素}

前報 [13]において連続乾熱処理法[ 14]により作成した 部分カルボキシメチル化綿布 (CM化布) のうち, Na 塩型 CMC Na 布 (図表中では CM Cot t on- Na) と酸型 CMC H布 (図 表中では CM Cot t on- H)について, 各々,DS=0. 10 と DS=0. 16 のものを使用した 酢素は前報と同樣 Novozynes 社の市販 セルラーゼ製剤 Cel l usof t L ( Tri choderm五 reesei 起源， 酵素活性: $750 \mathrm{EGU} / \mathrm{g}$ ) を光のまま使用した .

\section{2 酵素処理}

前報 [13] と同樣，末改質および $\mathrm{CM}$ 化布を $1 \mathrm{~cm} x 1 \mathrm{~cm}$ に カットし, 酵素濃度 $3.2 \mathrm{~g} / \mathrm{liter}$, 浴比 1: 25 , 酶酸緩衝液 (pH=5.0) 中で振とう式恒温槽 (振幅 40 mm, 100 回/min.)

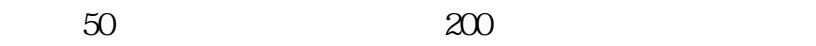
したものを使用した . また，本報では長時間処理として 12, 24, 48 時間処理を行った. 今回使用した試料の基本 データを, 前報から引用し表 1 に示す. 改質の DS は中和 滴定法により, 減量率 $(\mathrm{W})$ はセルラーセ処理前後の絶乾 重量からの計算により，また還元糖量（RS）は Sonogyi - Nel son の方法[ 15, 16]により測定した . 一方, 相 対吸水率( Rel at i ve water absor pti on) は, 前報において 以下の方法により算出した . 各改質綿布を,酵素処理と同 一の浴中処理条件において酵素を入れずに緩衝液 ( $\mathrm{pH}=0.50)$ のみで 50 分処理した後, 生地を処理浴から取り 出し, 吊下げて自重脱液して 5 分後の生地重量を測定し, 兴の絶乾重量から吸水率を算出した。光して, 未改質布 ( Sampl e A) の吸水率を 100 として, 各改質綿布の相対值で 表した .

\section{3 SEM 観察}

SEMによる㵶維表面のモルホロジー観察は,日本電子(狭) 製 JSMT100により行った .

\section{4 FT-IR 測定}

FT- IRによる赤外吸収スペクトルの測定は, 日本分光(妹) 製 FT/IR-460PI us を使用し，ATR法 (全反射法)により緎 維表面情報として測定した。

\section{5 塩基性染料の染着性}

セルラーゼ処理前後の各生地を C. I. Basi c Bl ue 105 により染色した. 染料 $5 \%$ (対生地重量), 浴比 1: 50 ,
$\mathrm{pH}=5.0$ で振とう式恒温槽（振幅 $40 \mathrm{~mm}, 100$ 回/min. ）にて $80^{\circ} \mathrm{C}$ で 60 分染色後, 水洗・湯洗・乾燥した . 各染色布の 可視部反射率曲線を(㑣)島津製作所製 UN-3100 自記分光光 度計により測定し，極大吸収波長における反射率から Kubel ka- Munk 式[17]により染色濃度 (K/S 值)を計算した 。

\section{3. 結果と考察}

\subsection{SEM による酵素処理綿布のモルホロジー観察} 未改質布ならびに $\mathrm{CM}$ 化布のセルラーゼ処理 200 分後の 繊維表面の状態を，処理前と比較し图 1 に示す.未改質布 (Sample A) には 200 分処理により深いクラックが生じて いることが確認された .これに対して親水性の大きい Na 塩型 CMC Na 布の場合，DS=0. 10 (Sampl e B) では処理前後 でほとんど変化がなく,クラックも認められず,セルラー ゼの作用が阻害されていることが確認できた . また， DS=0. 16 (Sample C) では 200 分処理により繊維表面が溶 解状態のように破壤されていることか確認できた .これは， CNG Na 布の親水性が大きく，繊維の膨潤により繊維表面 の一部が溶解またはセルラーゼの作用をより受けたため と考えられる.しかし，この場合においても繊維表面には 深いクラックか認められず，未改質布に対するセルラーゼ の作用とは異なった作用がなされたと考えられる．一方， 親水性の小さい酸型 CMC H 布の場合, DS=0.10 だけでなく DS=0.16 においても繊維表面の状態は処理前後でほとん ど变化がなく,クラックも認められず,セルラーゼの作用 が阻害されていることが確認できた .この場合には， CMC N N 布に比へ親水性の程度が低く繊維の膨潤による作 用が寄与しなかったものと考えられる .

そこで，セルラーセ処理時間を更に 12 時間および 24 時間，一部 CMC H 布については 48 時間とした場合の纎維 表面の状態を図 2 に示す. 未改質布 (Sample A) は 12 時 間処理において繊維表面全体に均一にセルラーゼの作用 を受け，纎維表面にフィブリルが平行に並んでいる状態が 確認できるようになる.更に 24 時間処理により，フィブ リルの形状か顕著に現れ,フィブリルが平行して並んでい る樣子が明確に確認できた .これは,セルラーゼ各成分の 相乗作用によりセルロース繊維の各フィブリルの間隙に 沿って加水分解が大きく進行したものと考えられる .これ

Table 1 Relative water absorption, weight loss activity(WL), and saccharification activity(RS) of samples used.

\begin{tabular}{cclcrc}
\hline Sample & Fabric & DS & Relative water absorption* & $\begin{array}{r}\text { WL }^{*} \\
(\%)\end{array}$ & $\begin{array}{c}\mathrm{RS}^{*} \\
(\mathrm{mg} / \mathrm{ml})\end{array}$ \\
\hline A & Unmodified & 0 & 100 & 10.4 & 1.97 \\
B & CM-Cotton-Na & 0.10 & 111 & 4.6 & 0.49 \\
C & CM-Cotton-Na & 0.16 & 134 & 12.9 & 0.94 \\
D & CM-Cotton-H & 0.10 & 100 & 2.4 & 0.40 \\
E & CM-Cotton-H & 0.16 & 118 & 2.7 & 0.34 \\
\hline
\end{tabular}

* Treatment with cellulase for $200 \mathrm{~min}$. 
に対して CMC Na 布の場合, DS=0. 10 (Sampl e B) では 200 分処理では認められなかった深いクラックが 12 時間処理 で認められ，24 時間処理においては纎維表面に個々のフ イブリルが平行に並んでいる状態が確認された . また， DS=0.16 (Sample C) では 200 分処理て現れていた溶解状 態が更に進み 12 時間 , 24 時間共にかなりの状態で溶解に よる纎維の破壤か観察された。しかし，この場合において も繊維表面には深いクラックは認められず,セルラーゼの 作用は未改質布に対する作用とは明らかに異なっている . 一方， CMC H 布の場合， DS=0.10 と DS=0.16共に 12 時間， 24 時間でほとんど変化がなく, 更に 48 時間処理において
はじめて DS=0.10 (Sampl e D) でわずかにクラックか認め られた .しかし，DS=0.16 (Sampl e E) では，ほとんど変 化が観察されなかった .

これまでの報告では[ 18]，水不溶性基質に対するセルラ 一ゼ各成分の作用を形態的に観察すると,エキソ型成分は

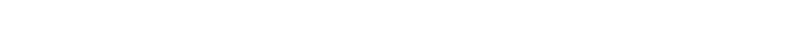
ル層に沿って深いクラックを生じさせる．これに対し，エ ンド型成分は繊維表面にわずかのクラックを生じさせる が, 各々のクラックは浅く,纎維表面のフィブリル層を全 体的にほぐし，溶かすような变化を示す.セルラーゼは多 成分系でセルロースを分解し，兴の際エンド型成分とエキ

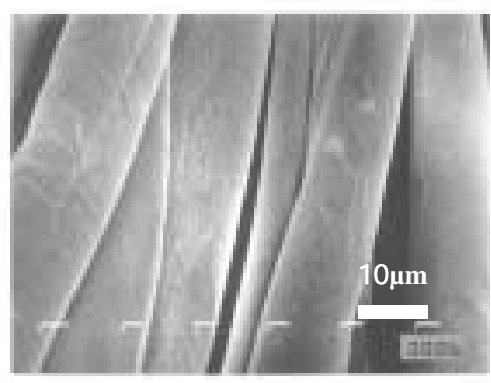

(A) untreated

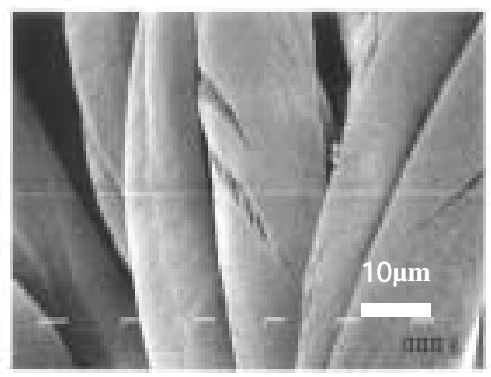

(A) treated for $200 \mathrm{~min}$.

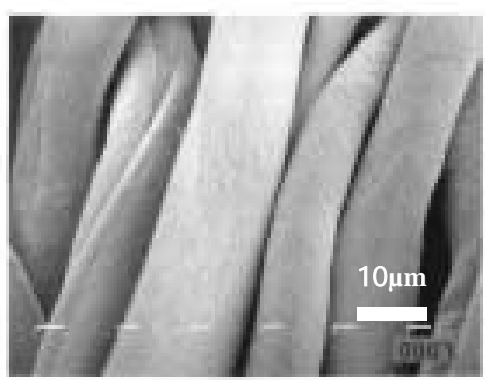

(B) untreated

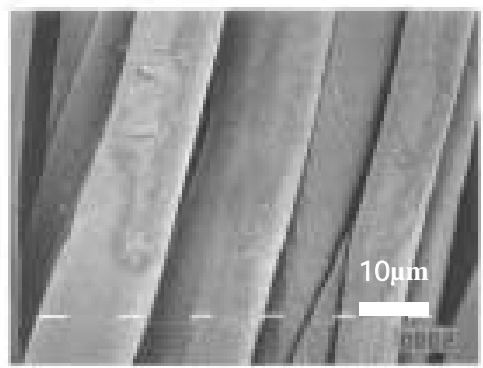

(B) treated for $200 \mathrm{~min}$.

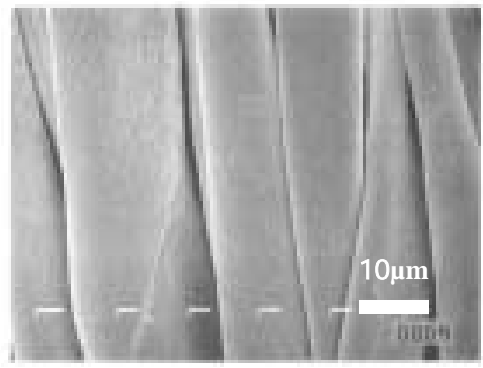

(D) untreated

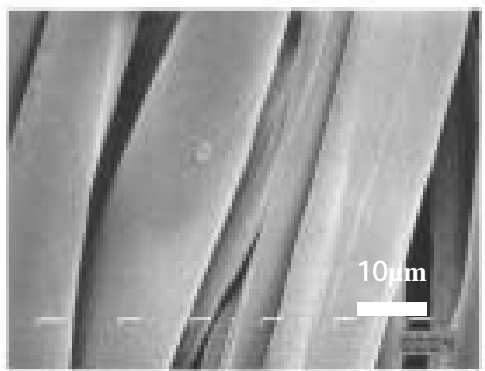

(D) treated for $200 \mathrm{~min}$.

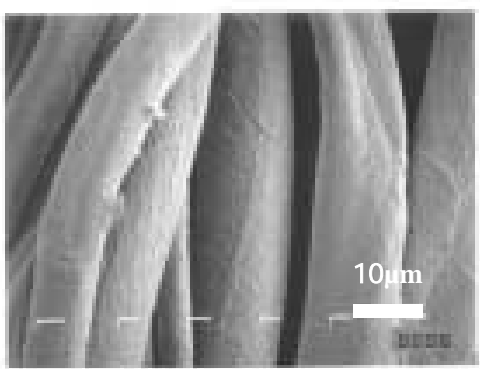

(C) untreated

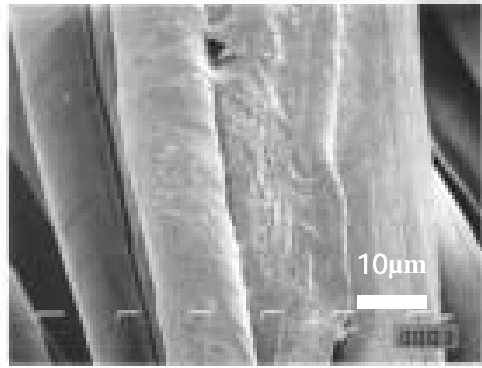

(C) treated for $200 \mathrm{~min}$.

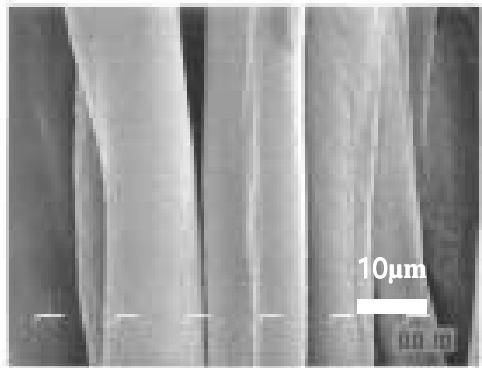

(E) untreated

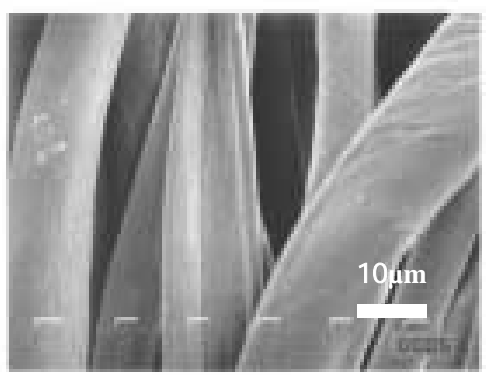

(E) treated for $200 \mathrm{~min}$.

Fig. 1 Scanning electron micrographs of the fiber surfaces of cotton treated with cellulase for $200 \mathrm{~min}$. 


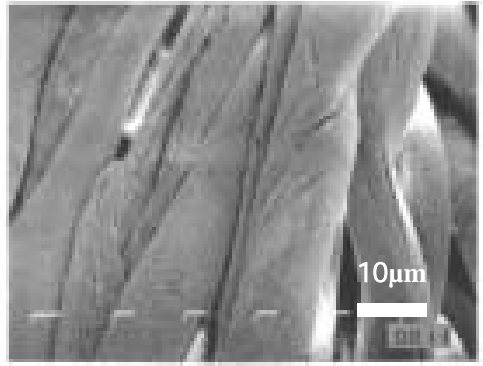

(A) treated for $12 \mathrm{hrs}$.

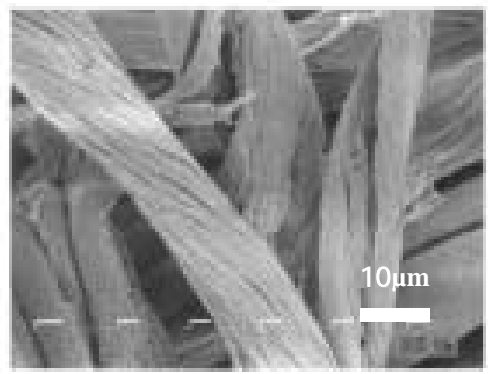

(A) treated for $24 \mathrm{hrs}$.

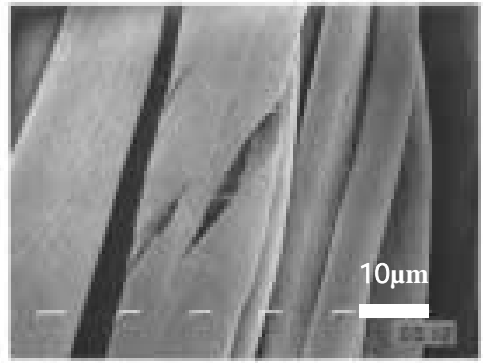

(B) treated for $12 \mathrm{hrs}$.

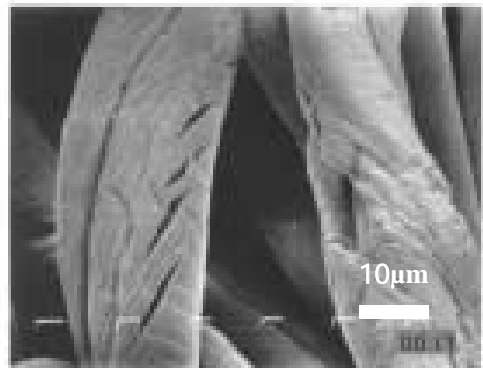

(B) treated for $24 \mathrm{hrs}$.

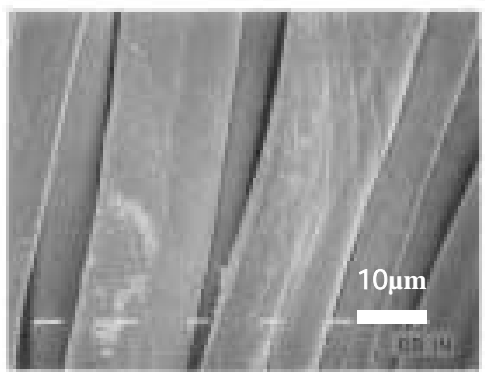

(D) treated for $12 \mathrm{hrs}$.

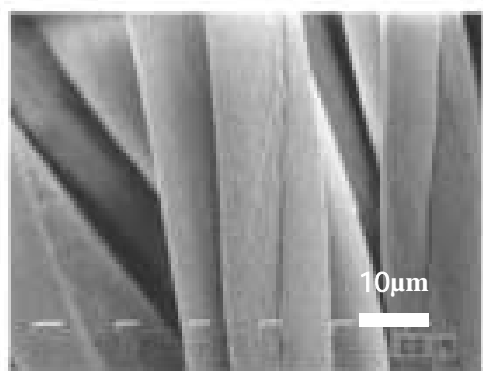

(D) treated for $24 \mathrm{hrs}$.

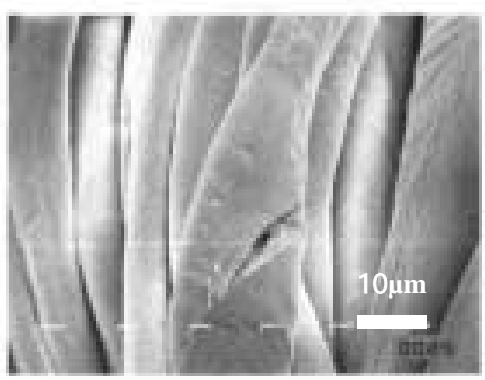

(D) treated for $48 \mathrm{hrs}$.

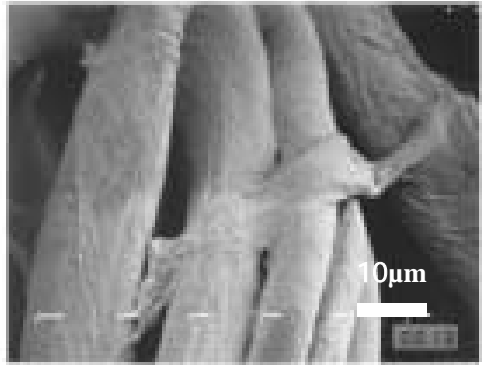

(C) treated for $12 \mathrm{hrs}$.

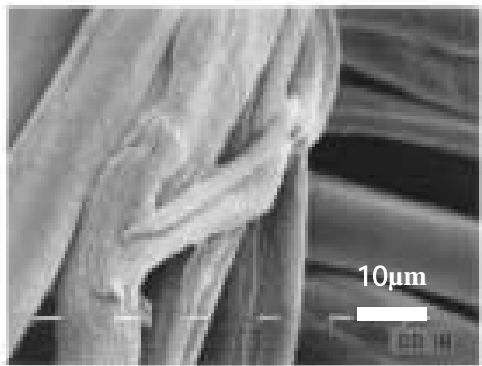

(C) treated for $24 \mathrm{hrs}$.

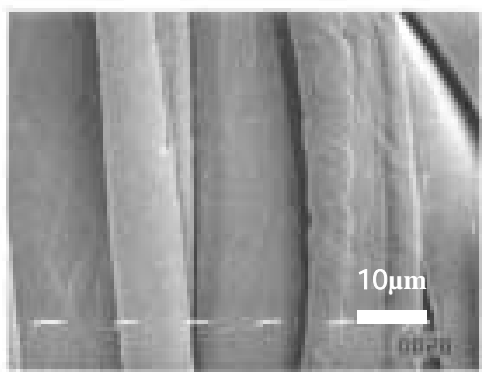

(E) treated for $12 \mathrm{hrs}$.

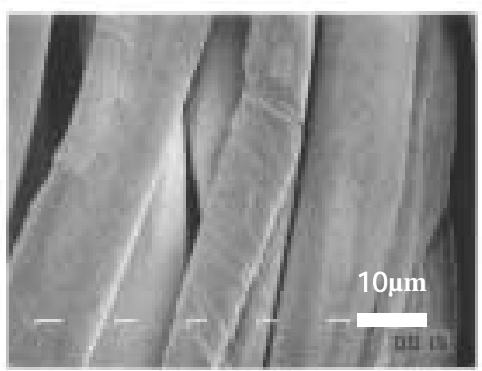

(E) treated for $24 \mathrm{hrs}$.

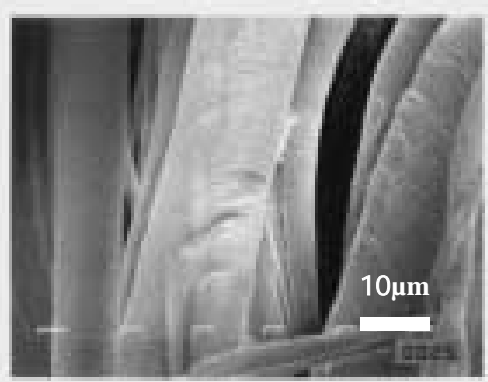

(E) treated for $48 \mathrm{hrs}$.

Fig. 2 Scanning electron micrographs of the fiber surfaces of cotton treated with cellulase for 12, 24 and $48 \mathrm{hrs}$. 
ソ型成分の相乗作用が重要と考えられている[19] .一般に エンド型成分は加水分解反応の度に基質から脱離する non- processi ve 的分解であり，エキソ型成分は加水分解 後も基質から脱離せず連続的に酵素反応が進行する processive 的分解とされている[20, 21] . 従って , これら のセルラーゼ各成分の作用を改質布の纎維表面の観察に 当てはめて考察すると，エキソ型成分は改質によるカルボ キシメチル基の立体障害により processi ve 的分解が阻害 され易いと考えられる.弚の結果, 繊維表面に深いクラッ クは生じないと考えられる。こに対して，エンド型成分 は,基質との結合と脱着が自由なので, 阻害の程度が小さ いであろう．前報[ 13]の結果から，CMC Na 布において減 量率の増加傾向に反して生成還元糖量が増加していない ことからも,エンド型成分よりもむしろエキソ型成分の作 用が阻害されていると考えられる。CNGNa 布の繊維表面 は繊維の膨潤により溶けているようには見えるが， DS=0. 16 程度の改質ではセルラーゼの作用無しに繊維自 身が溶解するには至らない これは水溶性基質に対するセ ルラーゼの作用に似て,エンド型成分が大きく寄与してい るものと考えられる .

更に,長時間のセルラーゼ処理において未改質布にフィ ブリルの明確な形状か観察されるのは,やはりエンド型成 分とエキソ型成分の相乗作用が大きく寄与しているもの と考えられる。長時間処理において，CMCNa 布では DS=0. 10 でクラックが認められるのに対して , DS=0.16で は溶解状態がより顕著になり，まったくクラックか認めら れない . DS=0.10では改質の程度が小さいので, エンド型
成分の作用が長く続いた結果としてクラックが生じたの か,あるいはエンド型成分の長時間の作用の結果, 繊維表 面の改質基が減少し未改質布と同樣の醰素作用が生じ，光 の結果エキソ型成分の作用が顕著に現れクラックが生じ たのかが判断できない，乥こで, セルラーゼ処理により改 質基であるカルボキシメチル基が減少しているか否かを， FT-IRおよび染料の染着性により検討した .

\section{2 FT-IRによる赤外吸収スペクトル}

FT-IRによる赤外吸収スペクトルの測定を ATR法で行う ことにより 繊維表面の情報が得られる 未改質布 (Sampl e A）についてセルラーゼ処理前ならびに CMC Na 布の DS=0. 10 ( Sampl e B) についてセルラーゼ処理前および 200 分，12 時間，24 時間の各処理布の吸収スペクトルを図 3 に示す. 未改質布のセルラーゼ処理前(1) と比較して, CMC Na布 DS=0.10のセルラーセ処理前( 2) の赤外吸収スペ クトルでは $1590 \mathrm{~cm}^{1}$ 付近 (カーソル位置) にカルボン酸塩 による $\mathrm{C}=0$ 伸縮の吸収か認められ，明らかにカルボキシメ チル化され Na 塩となっているものと考えられる.この CMC Na 布をセルラーゼ処理した場合の赤外吸収スペクト ル 200 分( 3)，12 時間( 4)，24 時間(5)においても，改質に 起因するカルボン酸塩による $\mathrm{C}=0$ 伸縮の吸収は依然とし て残存していることか確認できる.このことは，長時間の セルラーセ処理布の SEM観察において , 改質布がセルラー ゼによるダメージを受けながらも未処理布のような極端 なフィブリルの顕在化のような状態に至っていないこと とよく一致する .

一方，CMG Na 布の DS=0.16 (Sampl e C) についても ，

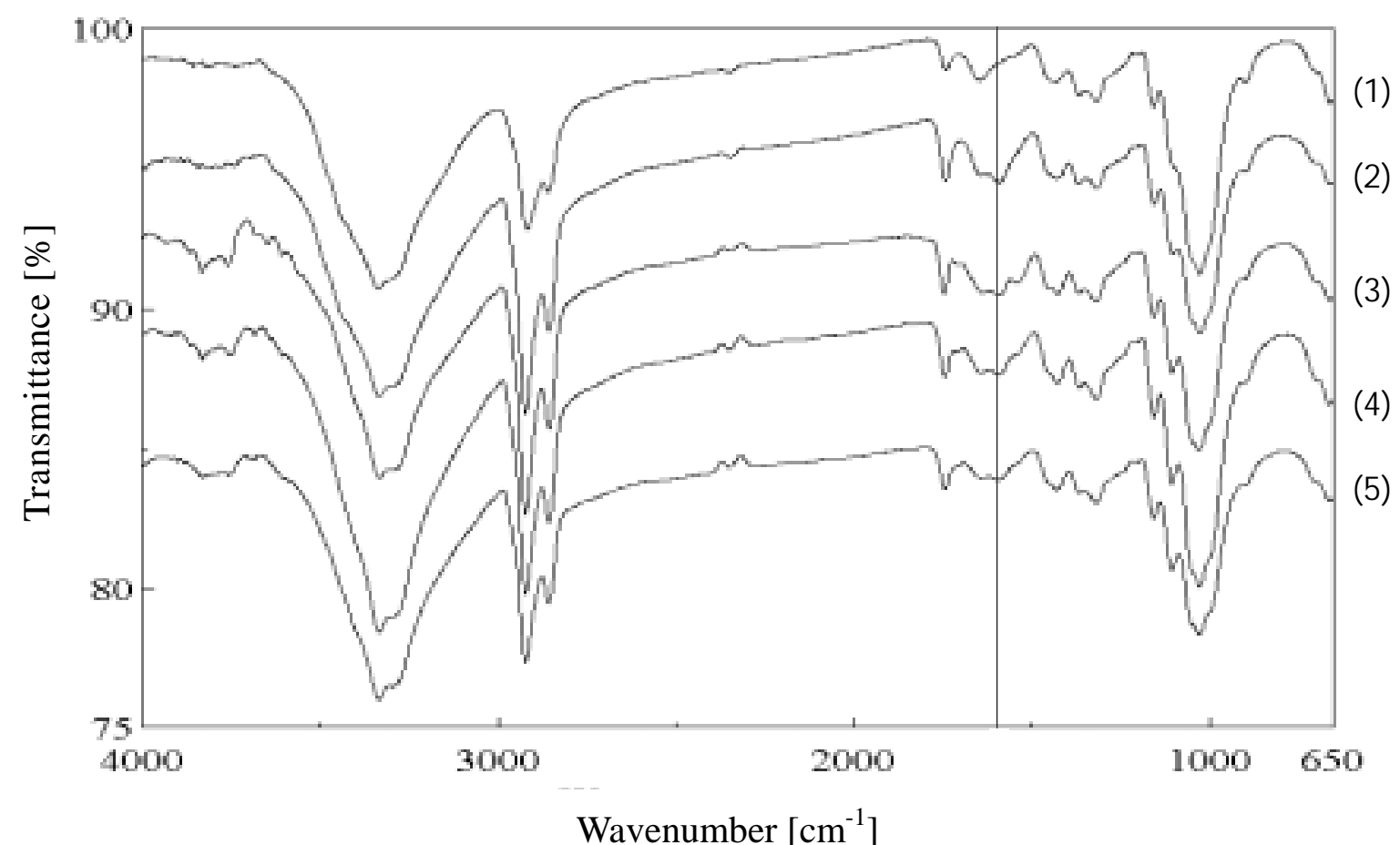

Fig. 3 FT-IR spectra of Sample A (unmodified cotton) and Sample B (CM-Cotton-Na with DS 0.10) treated with cellulase. (1) Sample A: untreated. (2) Sample B: untreated. (3) Sample B: treated for 200 min. (4) Sample B: treated for 12 hrs. (5) Sample B: treated for $24 \mathrm{hrs.}$ 


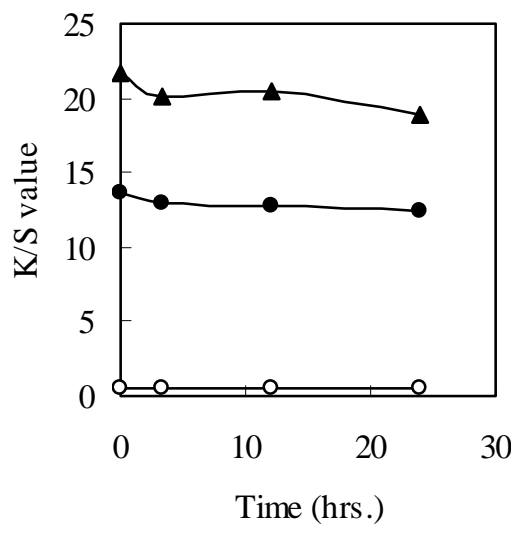

$\longrightarrow$ (C) CM-Cotton-Na with DS=0.16

$\rightarrow$ (B) CM-Cotton-Na with $\mathrm{DS}=0.10$

- - (A) Unmodified cotton

Fig. 4 K/S values of CM-Cotton-Na and unmodified cotton fabrics dyed with a basic dye against incubation time of cellulase treatment.

DS=0. 10 (Sampl e B) と同樣の吸収スペクトルを示した (図 (は省略) .このことも同樣に SEMからの考察でセルラーゼ によるダメージを受けていないことと一致する .

3.3 塩基性染料の染着性

$\mathrm{CM}$ 化布について, 弚の改質基としてのカルボキシメチ ル基の存在をセルラーゼ処理前後で確認するために , 綿污 染性の少ない塩基性染料( C. I. Basi c Bl ue 105) で染色し， 兴の染色濃度から考察した。

未改質布 (Sample A) と改質布 CMC Na 布の DS=0.10 (Sampl e B) , DS=0.16 (Sampl e C) の3 種類の生地につ いて 塩基性染料の染着性を染色濃度として K/S 值で現し， セルラーゼ処理時間に対してプロットした結果を図 4 に 示す.CMC Na 布の DS=0. 10 (Sampl e B) と DS=0.16 (Sampl e C) は共に塩基性染料で高濃度に染色され，アニオン基で あるカルボキシメチル基の存在を確認することが出来た . 一方，未改質布 (Sample A) はほとんど染色されず, 染色 濃度 K/S 值が DS を反映していることが確認できた . 図 4 において ,セルラーゼ処理の初期において若干の K/S 值の 低下か認められるが，処理時間が長時間にわたっても K/S 值が極端に低下しておらず,セルラーゼ処理によりカルボ キシメチル基が繊維表面から大きく減少していないこと か確認できる．このことは，FT-IRの赤外吸収スペクトル においてカルボン酸塩の $\mathrm{C}=0$ 伸縮の吸収ピークが大きく 減少していないこととよく一致している.すなわち, 改質 は綿繊維の非晶部においてなされていること，および長時 間のセルラーゼ処理においても改質基であるカルボキシ メチル基が減少していないことから，改質後の綿䋊維の非 晶部にはセルラーゼがほとんど作用しておらず,酵素作用 が明らかに阻害されていることが推察される．また，SEM によるモルホロジー観察の結果, 未改質布で認められた非 晶部の脱落による顕著なフィブリルの観察が改質布にお
いては認められず，また, 減量率が大きくSEM観察でも繊 維表面が溶解状態にあった CMC Na 布 DS $=0.16$ においても カルボキシメチル基が脱落していないことが推察できる.

\section{4. 結 論}

部分カルボキシメチル化綿の改質基質に対する市販セ ルラーゼ製剂の作用を，SEMによるモルホロジー観察， FT-IRによる赤外吸収スペクトル ,ならびに塩基性染料に よる染着性から検討した .

未改質布はセルラーゼの作用を大きく受け，深いクラッ クが発生した後にフィブリルが平行して並んでいる状態 が表面形状として顕著に観察された .これに対して，Na 塩型の CMC Na 布においては DS=0. 10 でセルラーゼの作用 が大きく阻害されており，長時間処理してはじめて形態変 化が認められた . また，DS=0.16では纎維の膨潤性が大き く，繊維表面を溶解させるような破壊が観察された .これ らの場合においても，䋊維表面にはクラックが生じにくく， 特にエキソ型成分の作用が大きく阻害されているものと 考えられる．これは，エキソ型成分の作用が processive 的分解と考えた場合, カルボキシメチル基による立体障害 により，阻害を受けやすいこととも一致している．一方， 繊維表面の溶解にはエンド型成分が主に作用しているも のと考えられる.また ,酸型の CMC H布においては纎維の 親水性が小さく膨潤の作用も少なく，また，DSによる改 質の差も小さい . 兴れゆえに，いずれのDSにおいてもセ ルラーゼの作用が阻害されることが観察された .

一方，FT-IRの吸収スペクトルから，セルラーゼ処理に より改質基であるカルボキシメチル基が減少していない ことが認められ，また，塩基性染料によるカルボキシメチ ル基の確認においても，FT- I R と同樣にセルラーゼ処理に よる改質基の減少がほとんど生じていないことが確認さ れた .従って，長時間反応においてもエキソ型成分への阻 害は継続していると推察される .

今後, 精製された分画酵素を用いて , 改質による基質の 立体障害がセルラーゼ各成分の作用にどのように影響を 及ぼすかにつき，より詳細な検討を続ける予定である．

\section{文 献}

1. M. Wadman, J. Soc. Dyers and Colourists, 110, 367 (1994).

2. A. Kumar, M. Y. Yoon, and C. Purtell, Textile Chemist and Colorist, 29, 37 (1997).

3. L. G. Snyder, Textile Chemist and Colorist, 29, 27 (1997).

4. R. Mori, T. Haga, and T. Takagishi, J. Appl. Polym. Sci., 45, 1869 (1992).

5. R. Mori, T. Haga, and T. Takagishi, J. Appl. Polym. Sci., 59, 1263 (1996). 
6. H. Koo, M. Ueda, and T. Wakida, Textile Res. J., 64, 70 (1994).

7. G. Buschle-Diller and M. K. Traore, Textile Res. J., 68, 185 (1998).

8. M. Ueda, H. Koo, and T. Wakida, Textile Res. J., 64, 615 (1994).

9. M. G. Wirick, J. Polym. Sci. A-1, 6, 1965 (1968).

10. K. E. Eriksson and B. H. Hollmark, Archi. Biochem. and Biophys., 133, 233 (1969).

11. S. S. Bhattacharjee and A. S. Perlin, J. Polym. Sci. C, 36, 509 (1971).

12. T. Kanda, K. Wakabayashi, and K. Nisizawa, $J$. Biochem., 87, 1635 (1980).

13. M. Yamada, Y. Amano, E. Horikawa, Y. Izawa, K. Nozaki, and T. Kanda, Sen'i Gakkaishi, 61, 13 (2005).
14. R. M. Reinhardt and T. W. Fenner, I \& E C Prod. Res.and Develop., 4, 82 (1965).

15. M. Somogyi, J. Biol. Chem., 195, 19 (1952).

16. N. Nelson, J. Biol. Chem., 153, 375 (1944).

17. P. Kubelka and F. Munk, Z. Tech. Phys., 12, 593 (1931).

18. E. Hoshino, Y. Sasaki, K. Mori, M. Okazaki, K. Nisizawa, and T. Kanda, J. Biochem., 114, 236 (1993).

19. E. Hoshino and T. Kanda, J. Appl. Glycosci., 44, 87 (1997).

20. T. Kanda and M. Samejima, Sen'i Gakkaishi, 55, P-193 (1999).

21. B. Henrissat, Cell. Commun., 5, 84 (1998). 